\title{
From Objects to Subjects of Religious Studies in Africa: Methodological Agnosticism and Methodological Conversion
}

\author{
Frans Wijsen
}

In reaction to late nineteenth-century (social) scientific studies of religion as an epiphenomenon of something else, whether structures of society or those of the mind, early twentieth-century phenomenological approaches attempted to study religion as a thing in itself. Due to secularization, among other factors, scholars of religion abandoned the phenomenological approach and its notion of religion as suigeneris in the early $1970 \mathrm{~s},{ }^{1}$ and advocated methodological agnosticism, at least in the West. Since then there has been a mostly hidden but sometimes manifest tension between "Western" and "non-Western" approaches, or dominant and peripheral voices in the study of religion, which call for a postcolonial approach. ${ }^{2}$ In this chapter I analyze a debate on these issues between members of the African Association for the Study of Religions (AASR) which was established at the first Regional Conference in Africa of the International Association for the History of Religions (IAHR), held at Harare in 1992. ${ }^{3}$

Based on the proceedings of this conference, one of the founding fathers of the AASR, Jan Platvoet, ${ }^{4}$ wrote a chapter entitled From Object to Subject for a volume he co-edited. In this chapter he described and analyzed the shift in the study of religion in Africa from the era in which Africa was the "object" of European historians, anthropologists, and theologians, to the era in which Africa became the "subject" of the study of religion in Africa. Platvoet ${ }^{5}$ con-

1 Gavin Flood, Beyond phenomenology. Rethinking the study of religion (London, New York: Cassell, 1999), 2-3.

2 Ibid., 230.

3 This chapter elaborates on a debate that I analyzed earlier in Frans Wijsen, "Are Africans Incurably Religious? Discourse Analysis of a Debate, Direction of a Discipline," Exchange 46, no. 4 (2017): $370-397$. The corpus is the same but the perspective is quite different. Unlike the previous article, in the present chapter I take a position in the debate in view of the topic of this book.

4 Jan Platvoet, "From object to subject. A history of the study of the religions in Africa," in The study of religions in Africa, eds. J. Platvoet, J. Cox and J. Olupona (Cambridge: Roots and Branches, 1996), 105-138.

5 Ibid., 129 . 
cluded that, "African scholars of African religions are now contributing their part to the worldwide academic study of the religions of humankind in a substantive manner." He immediately added that, "African scholars of African religions need to be in constant touch with that worldwide community in matters of methodology. They need to continue to contribute to, and to participate in, the critical discussion of the matter, motives and methods of the academic study of religions."

Two decades later, Jan Platvoet and his colleague Henk van Rinsum ${ }^{6}$ engaged in just such a critical discussion with a Nigerian AASR member, Kehinde Olabimtan. ${ }^{7}$ In this contribution I describe and analyze this "critical discussion," focusing on three points: the religious situation in Africa ("secularism" or "religious revival"); the underlying theory of religion ("mechanics" or "substance" of religion) and methodology ("religionist" or "agnostic"); and the view of science ("scientific," i.e., uncommitted, or "theological," i.e., the engaged study of religion). As a method I am inspired by critical discourse analysis as a form of ideology critique, ${ }^{8}$ particularly with respect to the mental maps that are drawn upon in the production and the consumption of the discourse. ${ }^{9}$

\section{Africa Is No More a Religious Continent than Europe}

In their "contestation" of Mbiti's view of religion in Africa, Platvoet and Van Rinsum ${ }^{10}$ examine one of John Mbiti's most cited statements, namely that Africans are incurably religious: "its explanation, p'Bitek's opposition to it, and recent evidence against it." According to them the statement was derived from the fact "that religion was not neatly separated from the other domains of society in pre-colonial Africa."11 But, in Platvoet and Van Rinsum's view, this conclusion is invalid. Mbiti correctly noted that African languages do not have a word for religion and do not separate the sacred and the secular. But, according

6 Jan Platvoet and Henk van Rinsum, "Is Africa incurably religious? Confession and contesting an invention," Exchange 32, 2 (2003): 123-153; J. Platvoet and H. van Rinsum, "Is Africa incurably religious? III. A reply to a Rhetorical Response," Exchange 37, 2 (2008): 156-173. Kehinde Olabimtan, "Is Africa incurably religious? II. A response to Jan Platvoet and Henk van Rinsum," Exchange 32, 4 (2003): 322-339.

8 Frans Wijsen, “There are radical Muslims and normal Muslims': an analysis of the discourse on Islamic extremism," Religion 43, 1 (2013): 70-88; Frans Wijsen and Kocku von Stuckrad (eds.), Making religion. Theory and practice in the discursive study of religion (Leiden, Boston: Brill, 2016).

$9 \quad$ Norman Fairclough, Discourse and Social Change (Cambridge: Polity Press, 1992), 71.

$10 \quad$ Platvoet and van Rinsum, "Is Africa incurably religious? I," 123.

11 Ibid., 135. 
to Platvoet and Van Rinsum, ${ }^{12}$ "from the absence of institutional differentiation and conceptual dichotomies in traditional cosmological and religious thought in African pre-colonial societies, one cannot conclude, as did Mbiti, that Africans were 'deeply religious."

There is quite some "verifiable historical data" to counter Mbiti's view. "Christianity became a dominant religion in modern Africa," Platvoet and Van Rinsum observe. ${ }^{13}$ But, "as a 'classroom religion,' it planted 'seeds of destruction' in itself." These are of two kinds. One is indigenous, the pragmatism of many Christians. The other is imported, namely formal education. Platvoet and Van Rinsum conclude:

[D]espite the full churches and the enthusiastic drumming and dancing, the number of people in Africa who are religiously indifferent, or inactive, nominal and critical believers seems to exceed by far those that are religiously committed, and those that practice their religion regularly. [Thus] Africa was, is and will basically be no more and no less a religious, and religiously indifferent, continent than Europe. ${ }^{14}$

In his response to Platvoet and Van Rinsum, Olabimtan 15 "attempts to uncover the weaknesses of the argument" by raising a number of critical questions.

If Africa is growing in secularism, as Platvoet and Van Rinsum argue to subvert the assertion of a deeply religious continent, how did African scholars in the Departments of Religious Studies gravitate away from the 'rationalist climate of unbelief,' in which they were supposedly trained, to a 'religionist' ethos,' as Platvoet and Van Rinsum note by citing the study Shorter and Onyancha ${ }^{16}$ on Secularism in Africa? [And] ... why has the dominant response to the economic and political crises on the continent, from Dakar through Cape Town to Mombasa, been religious, taking religiosity to mean the preponderant recourse to the transcendent as means of securely situating the self in a harsh and unpredictable world? ${ }^{17}$

According to Olabimtan: 
The twentieth century presented us with the dismal failure of the enlightenment movement in the two successive World Wars. In the consequent search for meaning beyond the pretensions of this movement, there reemerged in the West the alternative view to the prevailing irreligion. ... This renewed search for meaning found expression in the appreciation of the profundity of human existence and the plausibility of a transcendent reality beyond the mechanistic view that the enlightenment had hitherto espoused. ${ }^{18}$

In their reply to Olabimtan's response on this point, Platvoet and Van Rinsum ${ }^{19}$ say that Olabimtan "is entitled to these views." Nonetheless they write that they "find no support [for them] in the history of West European societies in the second half of the 2oth century. In them secularization has proceeded at a much faster pace than before 1950. A religious revival of any significant size has not occurred and is unlikely to occur in the coming decades." As evidence of this they say that

'the enlightenment' movement has become so powerful in academic theology, Protestant as well as Roman Catholic, in the past half century that, at least in the Netherlands, it has virtually 'de-theologized' Dutch academic Christian theology. Much of it has become indistinguishable from godsdienstwetenschap, the neutral, secular, non-privileging study of religions. ${ }^{20}$

Thus, "Olabimtan's exultation at an epistemological revolution in Western scholarship and a significant return to religion" is "disconfirmed by history."21

The latter statement, however, and the evidence given, is surprising in that Platvoet and Van Rinsum (2008: 158) start this article by analyzing the cause of the miscommunication between them and Olabimtan, namely the Christian and theological affiliation of the journal Exchange which published their first article. They complain that in the University of Utrecht, where the journal is published, "a neutral, non-confessional approach to the study of the religions of humankind was replaced with that of intercultural theology" (Platvoet and Van Rinsum 2003: 158). This is more or less the same situation as the one to which Platvoet and Van Rinsum (2003: 152) refer when they cite Shorter and Onyancha (1997: 19-22) who observed a stronger religious presence in

\footnotetext{
$18 \quad$ Ibid., 333.

19 Platvoet and van Rinsum,, "Is Africa incurably religious? III," 169.

$20 \quad$ Ibid.

$21 \quad$ Ibid.
} 
Departments of Religions Studies in Anglophone universities in Africa. This shows that the situation on the ground is much more complex and ambiguous than Platvoet and Van Rinsum's picture shows.

Thus, in terms of the production and the consumption of the discourse (Fairclough 1992: 67), both parties draw upon the book by Shorter and Onyancha (whose name is consistently misspelled in Platvoet and Van Rinsum 2003) on Secularism in Africa (1997), cited above, but use it in different ways. Platvoet and Van Rinsum (2003: 150) claim that they cite the study because "research into religious indifference and secularization is virtually a virgin field." They do not refer to numerous small and large-scale empirical studies that existed before the year they published their first article, and definitely before the year 2008 in which they published their second article: studies such as the Pew Forum on Religion and Public Life, the Gallup Polls, and last but not least the World Values Survey. ${ }^{22}$ These polls depend on how religion is defined, translated into operational terms, and measured, issues which are debatable. They nevertheless seem to point in the same direction: to a resurgence of religion in Africa or, at least, to a return of religion to the public domain - or, put differently, to "invisible religion" 23 becoming (more) visible.

Although Platvoet and Van Rinsum ${ }^{24}$ admit that Shorter and Onyancha study religious indifference for "normative reasons" rather than from a "neutral perspective," they point out that "they provide us with many useful data." Thus, whereas they first disqualify normative research as biased and prejudiced, they use Shorter and Onyancha's book to enhance their own point of view. Olabimtan, on the other hand, also uses the same book, meanwhile pointing out Platvoet and Van Rinsum's inconsistency. Olabimtan ${ }^{25}$ disqualifies Shorter and Onyancha's study, not because it is normative, but because it is too limited to be generalized. For, "how can data collected from a remote, affluent neighborhood of Nairobi be valid for all of Africa?" Platvoet and Van Rinsum, on the other hand, accuse Olabimtan of not presenting data to support his views, yet Olabimtan ${ }^{26}$ refers to Philip Jenkins' book on The Next Christendom, ${ }^{27}$ among others, which contains statistical data on the so-called "world-wide resurgence of religion" showing that the overwhelming majority of Africans say that they

22 Loek Halman et al., Changing values and beliefs in 85 countries. Trends from the values surveys from 1981 to 2004 (Leiden: Brill, 2008).

23 Thomas Luckmann, The Invisible religion. The transformation of symbols in industrial society (New York, Collier: Macmillan, 1967).

24 Platvoet and van Rinsum, "Is Africa incurably religious? I," 151.

25 Olabimtan, "Is Africa incurably religious? II," 334.

26 Ibid., 336.

27 Philip Jenkins, The Next Christendom. The Coming of Global Christianity (Oxford: Oxford University Press, 2002). 
are religious and that religion is important in their everyday lives, whatever this means.

Again, in terms of production and consumption of discourse, ${ }^{28}$ both parties also refer to p'Bitek's book on African Religions in Western Scholarship. ${ }^{29}$ Olabimtan ${ }^{30}$ asserts that Platvoet and Van Rinsum draw from p'Bitek's position to contest the alleged religiosity of Africa. But, according to him, p'Bitek's study is based on limited data of two groups only and, furthermore, that it harnesses the prejudices of Western scholars of African religions. According to Olabim$\tan ^{31}$ p'Bitek's "Western scientific method of inquiry" is in our time "fast losing ground to a new movement - the postmodern - as the unassailable method of inquiry in the study of cultures."

Platvoet and Van Rinsum ${ }^{32}$ dismiss Olabimtan's claim on the formal ground that the postmodern appeared only after p'Bitek's death. They do not say that the methodological battle which Olabimtan refers to as positivism versus postmodern has been going on in the academic study of religion for decades under different labels - empirical versus hermeneutical study of religion, science versus humanities, explanation versus interpretation - and that postmodernism is no longer at the periphery but at the center of religious studies, ${ }^{33}$ if one wishes to speak in these terms.

From an empirical point of view, it is striking that Platvoet and Van Rinsum speak in the future tense more than once. "Africa was, is and will basically be no more and no less a religious, and religiously indifferent, continent than Europe,"34 adding that "a religious revival of any significant size has not occurred and is unlikely to occur in the coming decades." 35 This demonstrates an ideological element in their analysis, an implicit evolutionary theory of religion. In sociology, and even more so in the sociology of religion, it is generally accepted how difficult it is to provide trend scenarios. For example, in the Cold War era, who could have predicted that religion would revive in China and Russia after the collapse of the Berlin War? Scholars who are trained in the social sciences and empirical methods would hesitate to make such massive claims about the future of religion.

28 Fairclough, Discourse, 67.

29 Okot p'Bitek, African religions in Western scholarship (Nairobi: Kenya Literature Bureau, 1970).

$30 \quad$ Olabimtan, "Is Africa incurably religious? II," 329.

$31 \quad$ Ibid., 327.

32 Platvoet and van Rinsum, "Is Africa incurably religious? III," 168.

33 Flood, Beyond phenomenology.

34 Platvoet and van Rinsum, "Is Africa incurably religious? I," 153.

35 Platvoet and van Rinsum, "Is Africa incurably religious? III," 169. 
Platvoet and Van Rinsum refer to p'Bitek's "confession" that he was "neither a Christian nor a pagan" and that he did "not believe in gods or spirits." ${ }^{36}$ p'Bitek nevertheless had a Christian funeral and he was buried in the graveyard next to St Philips, the Church of Uganda Cathedral in Gulu. This is not mentioned to show that he was inauthentic but rather that religion is ambiguous, and that human life is more complex than clear-cut categories such as "atheist" versus "religious" suggest.

\section{Religions Are Best Understood in Their Extra-religious Contexts}

Drawing upon the "invention of tradition" theory, ${ }^{37}$ Platvoet and Van Rinsum ${ }^{38}$ interpret Mbiti's statement about Africans being notoriously religious as understandable but false: a "post-colonial counter-invention against the precolonial and colonial European inventions of Africa as primitive, savage, without a religion, pagan, superstitious, full of witchcraft, witch hunts, sorcery and black magic." Thus, they suggest, Mbiti and others have overemphasized that Africans were deeply religious in a reaction to these "inventions." But, they add, the invention and counter-invention "contain more ideology than fact, being extrapolated from very limited historical data in highly selective and biased ways." 39 They say that "[p]articular historical data on the single indigenous religions, if put into their own extra-religious contexts, point to a much more varied and variable picture." 40

In his response to Platvoet and Van Rinsum, Olabimtan ${ }^{41}$ argues that Platvoet and Van Rinsum only discuss the "mechanics" of religion and not its "substance," along with its "intellectual component" (belief) more than its pragmatic component (ritual). He further suspects ${ }^{42}$ that, in criticizing Africa's "religious pragmatism" as if it were not real or authentic religion, Platvoet and Van Rinsum ${ }^{43}$ are taking an elitist, intellectualist view of religion, and he

$36 \quad$ Platvoet and van Rinsum, "Is Africa incurably religious? I," 139.

37 Terence Ranger, "The Invention of Tradition in Colonial Africa," in The Invention of Tradition, eds. E. Hobsbawm and Terence Ranger (Cambridge: Cambridge University Press, 1983) 211-262; Terence. Ranger, "The Invention of Tradition Revisited," in Legitimacy and State in Twentieth-Century Africa, eds. T. Ranger and O. Vaughan (London: MacMillan Press, Ltd. 1993), 62-111.

38 Platvoet and van Rinsum, "Is Africa incurably religious? I," 135.

39 Ibid., 153.

40 Ibid.

41 Olabimtan, "Is Africa incurably religious? II," 323.

42 Ibid., 334.

43 Platvoet and van Rinsum, "Is Africa incurably religious? I," 149. 
poses the rhetorical question: "[A]re Platvoet and Van Rinsum saying that Western Christianity is the eternal and immutable norm of the faith of the church?"44 According to Olabimtan, ${ }^{45}$ " $[\mathrm{t}]$ he problem is still the unwillingness of the secular Western method of intellectual inquiry to allow the nature of religion to shape the methods of its inquiry."

In their response to Olabimtan, Platvoet and Van Rinsum ${ }^{46}$ claim that Olabimtan does not tell them "what the 'mere mechanics' of religion are, and what he regards as the 'substance' of religion," and that "religions should be studied both in their religious function, as (postulated) communication, communion and commerce with 'unseen' worlds, beings and processes, and their numerous non-religious functions in their contexts." They reconfirm that academic scholars can only pursue two kinds of knowledge about religions, historical and ethnographic, along with generalized insights won from their comparative study. ${ }^{47}$

Being outside the perimeter of the empirical world, or hidden within it in non-observable, non-testable manners, the meta-empirical, and infra/ intra-empirical, cannot be made subject of scientific investigation, and so can neither be scientifically verified nor falsified. ${ }^{48}$

Thus, the substance of religion cannot dictate the methods of inquiry. Only the functions of religion can be studied in a scientific way.

Whereas Platvoet and Van Rinsum ${ }^{49}$ claim that Olabimtan does not explicate what he regards as the substance of religion, in fact he does clarify this by describing religion as "the preponderant recourse to the transcendent" and the "plausibility of a transcendent reality." ${ }^{50}$ Indeed, this comes close to what Platvoet and Van Rinsum themselves say when they distinguish "(postulated) communication, communion and commerce with 'unseen' worlds" and their "numerous non-religious functions in their context." But they define the former "(postulated) communication" as religious "function,"51 not as substance. But what else is "(postulated) communication, communion and commerce with 'unseen' worlds, beings and processes" than substance? Olabimtan

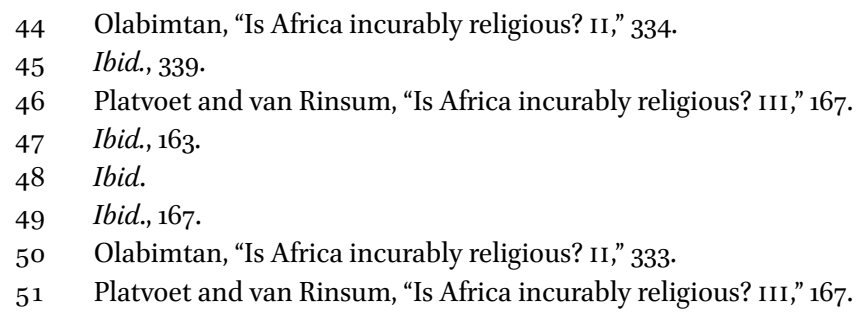


himself distinguishes what religion is, its substance, namely "the preponderant recourse to the transcendent," from what it does, its function, namely "securely situating the self in a harsh and unpredictable world." ${ }^{2}$ Platvoet and Van Rinsum's definition of religion moreover shows that, unlike Olabimtan's claim, they not only speak about religion as an intellectual enterprise, but also as practice; religion as "commerce."

It is precisely the relation between subject and object of science which lies at the heart of the modern versus postmodern epistemology. ${ }^{53}$ Do scholars accept the correspondence theory of knowledge, in which knowledge is true if the mental representations of reality correspond with the reality itself, assuming there is such reality: a form of essentialism in which religion is perceived as an entity? Or do they assume that the representations of reality contribute to the construction of reality, a conversation type of epistemology: religion as a construct? ${ }^{54}$ But here we leave the theory of methods (methodology) to the corresponding views of science.$^{55}$ Platvoet and Van Rinsum ${ }^{56}$ may be right that there is no "epistemological revolution in Western scholarship," but at least there is a "postmodern turn" which also applies to religious studies. ${ }^{57}$

When Platvoet and Van Rinsum ${ }^{58}$ give proof of the irreligiosity and religious indifference of Africans, saying that the people who are religiously indifferent seem to exceed by far those that practice their religion regularly, they do give the impression that, to them, attendance is the most important criterion for measuring religion, and that "pragmatism" is not "real" religion. ${ }^{59}$ From studies of secularization in the West which equate sociology of religion with sociology of the Church, Western scholars of religion know how problematic this perspective is. The issue is not how religious people are, but how they are religious. In their reaction to Olabimtan's critique, Platvoet and Van Rinsum ${ }^{60}$ rightly point to Platvoet's numerous studies in which he has shown that "magic" is a form of religion, as discussed above. But, with regards the way they describe religious pragmatism, Olabimtan seems to have a point.

52 Olabimtan, "Is Africa incurably religious? II," 335.

53 Flood, Beyond phenomenology, 150.

54 Jonathan Smith, Imagining Religion, from Babylon to Jonestown (Chicago: University of Chicago Press, 1982).

55 C. Du Toit, "The restoration of subjectivity in science, rationality and knowledge systems as a precondition for scientific integrity," in The Impact of Knowledge Systems on Human Development in Africa, ed. C. Du Toit (Pretoria: University of South Africa, 2007), 70-75.

56 Platvoet and van Rinsum, "Is Africa incurably religious? III," 169.

57 Russell McCutcheon, Studying religion. An introduction (London - Oakville: Equinox, 2007).

58 Platvoet and van Rinsum, "Is Africa incurably religious? I," 150.

59 Ibid., 149.

6o Platvoet and van Rinsum, "Is Africa incurably religious? III," 165-166. 


\section{There Is No Science but Empirical Science}

In criticizing Mbiti's counter-invention and ideology, Platvoet and Van Rinsum note that

[o]nly by means of historical studies of single 'traditional' African societies can one establish whether 'religion' did pervade them deeply, or superficially, or not at all, or in variable ways, or in some other manner. Any view, maximal or minimal, must be founded on verifiable historical data, if academic status is claimed for it. ${ }^{61}$

According to Olabimtan, ${ }^{62}$ Platvoet and Van Rinsum give substance to "p'Bitek's atheistic position" and by doing so "they demonstrate their allegiance to the old, secularist school." But, in Olabimtan's view, this “so-called scientific method of inquiry no longer holds the ace in investigating societies. It is a demystified notion that what is unscientific is not real." ${ }^{63}$ As we have seen already, according to Olabimtan 64 "the two major wars of the twentieth century ... signify a [violent] turning point in the intellectual history of the modern world" and "the dominance of the scientific approach may have seen the best of its days prior to [this]." 65 The "turning point" made possible a "renewal of a view that has always existed in the West but dominated by an irreligious perspective fostered by the enlightenment movement," namely a religionist view of "scholars of religion who take seriously the proposition of inherent transcendence in religion," in Europe as well as elsewhere. ${ }^{66}$

In their reply to this, Platvoet and Van Rinsum ${ }^{67}$ argue that their position is not atheistic but agnostic, and that "methodological agnosticism" has become the leading position between the warring camps of positivism and religionism during the past half century in the academic study of religions. Moreover, they assert, theirs is no longer solely a European stance in that a number of leading scholars in the world share the conviction that they must teach this model to their successors. ${ }^{68}$ According to them there is no science but empirical

\footnotetext{
61 Platvoet and van Rinsum, "Is Africa incurably religious? I," 142-143.

62 Olabimtan, "Is Africa incurably religious? II," 333.

63 Ibid.

64 Ibid., 328.

65 Ibid., 338.

66 Ibid., 333 .

67 Platvoet and van Rinsum, "Is Africa incurably religious? III," 162.

68 Platvoet and van Rinsum, "Is Africa incurably religious? III," 165.
} 
science, ${ }^{69}$ repeating that meta-empirical postulations cannot be verified or falsified and thus are unscientific. ${ }^{70}$

This is an ideological statement in the sense that it naturalizes a contingent reality. Religious studies are conducted from at least two views of science with corresponding knowledge interests - contextual and hermeneutic, explanatory or interpretative - and the latter "may be not less objective in its approach than the self-acclaimed scientific approach." ${ }^{.11}$ Moreover, the argument that a number of leading scholars in the world share the conviction that they must teach this model to their successors can be reversed: a number of leading scholars in the world share the conviction that they must teach an alternative model to their successors, a more constructivist model.

Whereas Olabimtan ${ }^{72}$ says that "the landscape of academic study of religions of Africa" is not "a monolith," and "there are many perspectives" and regular shifts to "another perspective," Platvoet and Van Rinsum ${ }^{73}$ recognize only one form of science. They say that, "there is no other" science than "empirical science." This is scientific investigation that can be verified or falsified: historical, ethnographic, and comparative. They fix the meaning of the word "science" to its use in the Anglo-Saxon world, where science is always "exact science." This is not the meaning of the word in the original German term Religionswissenschaft where science includes the humanities. In Germany, religious studies as a discipline is closer to cultural studies, ${ }^{74}$ including cultural anthropology, which operates at the boundary of science and humanities, interpretation and explanation. Platvoet and Van Rinsum, ${ }^{75}$ however, claim that "any view ... must be founded on verifiable historical data if academic status is claimed for it."

But, what is "verifiable historical data"? Is this data supposed to show how the past really was, in harmony with Von Ranke's ideal of objective history? And does this signify that knowledge which is not founded on "historical verifiable data" is not academic? The discourse is framed in a specific vocabulary, "falsification" and "verification," taken from only one view of science, the neopositivistic view. This is what Olabimtan ${ }^{76}$ refers to as a "claim of science to truth."

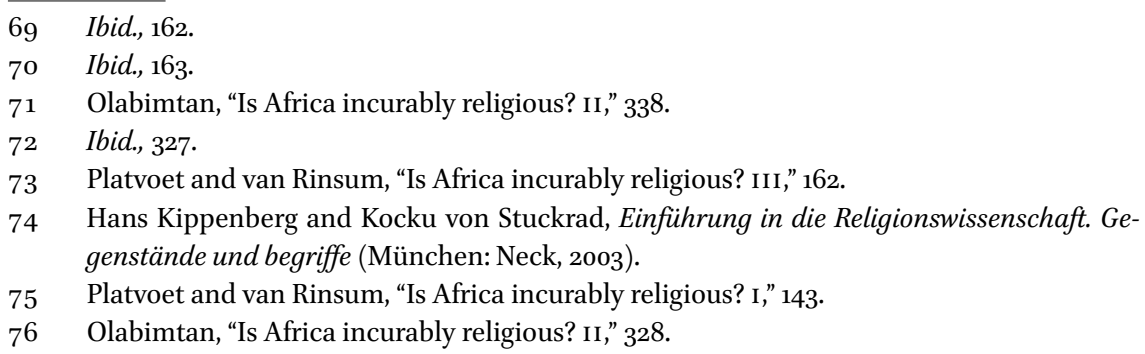


By making use of insights developed in critical discourse analysis as a form of ideology critique, it became apparent to me that the accusation that Platvoet and Van Rinsum make of Mbiti's work, namely that it contains "more ideology than fact," also applies to their own scholarship. I immediately add that this is nothing to worry about. Unlike Platvoet and Van Rinsum, who adhere to the notion of neutral and objective science, I am convinced that (social) science is always ideological to a certain extent. Drawing on Bourdieu, ${ }^{77}$ this is not a problem as long as scholars remain self-reflexive and critical of their perspectives.

Going back to Jan Platvoet's chapter on the proceedings of the Harare conference with which I started, this is the heart of the matter. Platvoet ${ }^{78}$ observes that, "African scholars of African religions are now contributing their part to the worldwide academic study of the religions of humankind in a substantive manner." But they "need to be in constant touch with that worldwide community in matters of methodology" if they are to produce "better and more 'objective' knowledge" (note that objective is put between inverted commas showing that Platvoet was aware of the complexity of objectivity in science). This is knowledge which can be accepted as "valid" by the "global scientific community" which is or ought to be a "democratic community of organized skepticism."79

But this is exactly the point raised by the above analysis. How democratic is this global scientific community? According to many non-Western members of the International Association of the History of Religions (IAHR), and its daughter organization, the African Association for the Study of Religions (AASR), these professional societies are still dominated by Western scholars who have a background in Christian liberal theology. There seems to be a universality claim for the principle of methodological agnosticism which is not very helpful in non-Western and non-Christian contexts. ${ }^{80}$ Platvoet and Van Rinsum ${ }^{81}$ confuse "religious" with "privileging" scholarship, "objective" with "disengaged," and they equate being normative with being prejudiced, which is not necessarily

77 Pierre Bourdieu, In other words. Essays towards reflexive sociology (Stanford, CA: Stanford University Press, 1990).

78 Platvoet, "From object to subject,"129.

79 Ibid., 130.

8o Zainal Bagir and Irwan Abdullah, "The development and role of religious studies. Some Indonesian reflections," in Islamic Studies and Islamic Education in Contemporary Southeast Asia, eds. K. Bustamam-Ahmad and P. Jory (Kuala Lumpur:Yayasan Ilmuwan, 2011), 69.

81 Platvoet and van Rinsum, "Is Africa incurably religious? I"; Platvoet and van Rinsum, "Is Africa incurably religious? III." 
the case. As various Centers for Religious Studies in both non-Western and Western worlds show, one can be religiously engaged without privileging one religion above another. ${ }^{82}$

At the Harare conference, James $\operatorname{Cox},{ }^{83}$ who is also a founding father of the AASR, argued that the scholar of African religion must develop a capacity "to see as a believer sees." Cox ${ }^{84}$ made a plea for a "methodological conversion," which is not the same as "confessional conversion." Methodological conversion draws on Wittgenstein's analysis of language games. "It does require a form of epochè, but rather than endeavoring to bracket out all of one's preconceived academic and personal convictions, it suggests that one can hold differing and even contradictory presuppositions at the same time." ${ }^{85}$ Not only their objects of study, but scholars of religion themselves are polyphonic, and the ambiguity in p'Bitek's work to which I referred above is an example of this. I find this a relevant and legitimate principle in the academic study of religion, not as a replacement for, but as an alternative to, methodological agnosticism.

\section{References}

Bagir, Zainal and Irwan Abdullah. "The development and role of religious studies. Some Indonesian reflections." In Islamic Studies and Islamic Education in Contemporary Southeast Asia, edited by K. Bustamam-Ahmad and P. Jory, 57-73. Kuala Lumpur: Yayasan Ilmuwan, 2011.

Bourdieu, Pierre In other words. Essays towards reflexive sociology. Stanford, CA: Stanford University Press, 1990.

Cox, James Rational ancestors. Scientific rationality and African Indigenous Religions. Cardiff: Cardiff Academic Press, 1998.

Du Toit, C. "The restoration of subjectivity in science, rationality and knowledge systems as a precondition for scientific integrity." In The Impact of Knowledge Systems on Human Development in Africa, edited by C. Du Toit, 667-697. Pretoria: University of South Africa, 2007.

Fairclough, Norman. Discourse and Social Change. Cambridge: Polity Press, 1992.

Flood, Gavin. Beyond phenomenology. Rethinking the study of religion. London - New York: Cassell, 1999.

\footnotetext{
$82 \quad$ Bagir and Abdullah, "The development."

83 James Cox, Rational ancestors. Scientific rationality and African Indigenous Religions (Cardiff: Cardiff Academic Press, 1998), 155.

84 Ibid., 164.

85 Ibid., 168.
} 
Halman, Loek, et al. Changing values and beliefs in 85 countries. Trends from the values surveys from 1981 to 2004. Leiden: Brill, 2008.

Jenkins, Philip The Next Christendom. The Coming of Global Christianity. Oxford: Oxford University Press, 2002.

Kippenberg, Hans and Kocku von Stuckrad. Einführung in die Religionswissenschaft. Gegenstände und Begriffe. München: Neck, 2003.

Luckmann, Thomas. The Invisible religion. The transformation of symbols in industrial society. New York - Collier: Macmillan, 1967.

McCutcheon, Russell. Studying religion. An introduction. London - Oakville: Equinox, 2007 .

Olabimtan, Kehinde. "Is Africa incurably religious? II. A response to Jan Platvoet and Henk van Rinsum." Exchange 32, no. 4 (2003): 322-339.

p'Bitek, Okot. African religions in Western scholarship. Nairobi: Kenya Literature Bureau, 1970.

Platvoet, Jan. "From object to subject. A history of the study of the religions in Africa." In The study of religions in Africa, edited by J. Platvoet, J. Cox and J. Olupona, 105-138. Cambridge: Roots and Branches, 1996.

Platvoet, Jan \& Henk van Rinsum. "Is Africa incurably religious? Confession and contesting an invention." Exchange 32, no. 2 (2003): 123-153.

Platvoet, Jan. \& Henk van Rinsum. "Is Africa incurably religious? III. A reply to a Rhetorical Response." Exchange 37, no. 2 (2008): 156-173.

Ranger, Terence. "The Invention of Tradition in Colonial Africa." In The Invention of Tradition, edited by E. Hobsbawm \& T. Ranger, 211-262. Cambridge: Cambridge University Press, 1983 .

Ranger, Terence. "The Invention of Tradition Revisited." In Legitimacy and State in Twentieth Century Africa, edited by T. Ranger \& O. Vaughan, 62-111. London: MacMillan Press, Ltd. 1993.

Shorter, Aylward. \& Edwin Onyancha. Secularism in Africa. A Case Study: Nairobi City. Nairobi: Paulines Publications, 1997.

Smith, Jonathan. Imagining Religion, from Babylon to Jonestown. Chicago: University of Chicago Press, 1982.

Wijsen, Frans. “There are radical Muslims and normal Muslims': an analysis of the discourse on Islamic extremism." Religion 43, no. 1 (2013): 70-88.

Wijsen, Frans. "Are Africans Incurably Religious? Discourse Analysis of a Debate, Direction of a Discipline," Exchange 46, no. 4 (2017): 370-397.

Wijsen, Frans. \& Kocku von Stuckrad (eds.) Making religion. Theory and practice in the discursive study of religion. Leiden - Boston: Brill, 2016. 